\title{
CLIP (Cross-Linking and Immunoprecipitation) Identification of RNAs Bound by a Specific Protein
}

\author{
Robert B. Darnell
}

Guilt by association remains a powerful argument for assigning function in biological processes: Proteins that bind a specific RNA are strongly implicated in modulating the fate and action of that RNA. Detecting such associations is a major goal in understanding RNA function. The cross-linking and immunoprecipitation (CLIP) method described here allows assignments of RNA-binding proteins to their RNA targets by using ultraviolet (UV) cross-linking to covalently capture close (near-covalent bond distances) association of RNA with protein, followed by immunopurification of the protein partner with extraction and subsequent characterization of the RNA partner sequence(s). Pools of target sequences can be captured and their genomic origins are studied so that regulatory and other functional relationships between the protein and its RNA targets can be inferred. The advantage of this protocol is that it captures only intimately associated RNAs and proteins, and so is expected to be highly specific. Some investigators report capturing cross-links between rRNA and nonribosomal proteins in cases where ribosomes are not efficiently cleared from the lysate before immunopurification of the target protein, so the limits of specificity for the method are yet to be fully explored. Its main disadvantages are its many steps and that it may fail to work for all proteins or capture all legitimate targets of any given protein if the necessary chemical groups are not optimally arranged for photocrosslinking in the complex. However, properly performed, this method should provide many useful insights into the nature of the RNA ligands for an RNA-binding protein of interest.

It is essential that you consult the appropriate Material Safety Data Sheets and your institution's Environmental Health and Safety Office for proper handling of equipment and hazardous materials used in this protocol.

RECIPES: Please see the end of this article for recipes indicated by $<R>$. Additional recipes can be found online at http://cshprotocols.cshlp.org/site/recipes.

\section{Reagents}

3' RNA linker, gel purified, L3: 5'-P-GUGUCAGUCACUUCCAGCGG-3'-puromycin

$5^{\prime}$ RNA linker, gel purified, L5: 5'-OH-AGGGAGGACGAUGCGG-3'-OH

Accuprime Pfx Supermix (Invitrogen)

Acrylamide:bis-acrylamide (19:1)

Adenosine phosphosulfate (APS; 10\%)

Antibody against the protein of interest

Adapted from RNA: A Laboratory Manual, by Donald C. Rio, Manuel Ares Jr, Gregory J. Hannon, and Timothy W. Nilsen. CSHL Press, Cold Spring Harbor, NY, USA, 2011.

(C) 2012 Cold Spring Harbor Laboratory Press

Cite this article as Cold Spring Harb Protoc; 2012; doi:10.1101/pdb.prot072132 
$\operatorname{ATP}(1 \mathrm{~mm}, 10 \mathrm{~mm})$

Bovine serum albumin (BSA, $100 \mu \mathrm{g} / \mathrm{mL}$ ) in RNase-free water

Calf intestinal alkaline phosphate (CIP)

Chloroform:isoamyl alcohol (49:1)

Dephosphorylation buffer (10×; Roche 712023)

Dithiothreitol (DTT; $0.1 \mathrm{M}$ )

DNA P3-454 capture primer: 5'-GCCTTGCCAGCCCGCTCAGCCGCTGGAAGTGACTGACAC-3' $(100 \mu \mathrm{M})$

DNA P3 primer: 5'-CCGCTGGAAGTGACTGACAC-3' (30 pmol/ $\mu \mathrm{L})$

DNA P5-454 capture primer: 5'-GCCTCCCTCGCGCCATCAGAGGGAGGACGATGCGG-3' (100 $\mu \mathrm{M})$

DNA P5 primer: 5'-AGGGAGGACGATGCGG-3' (30 pmol/ $\mu \mathrm{L})$

DNase I buffer

dNTP $(3 \mathrm{~mm})$

EDTA

Ethanol (75\%)

Ethanol:isopropanol $(1: 1)$

$\left[\gamma^{3}{ }^{32} \mathrm{P}-\right]$ ATP $(10 \mu \mathrm{Ci} / \mu \mathrm{L})$

Glycogen (Ambion)

Hanks' balanced salt solution (HBSS), $\mathrm{Ca}^{2+}-\mathrm{Mg}^{2+}$ free (GIBCO), 10 mM HEPES (pH 7.3)

Low-molecular-weight marker (e.g., Amplisize Molecular Ruler, Bio-Rad)

Micrococcal nuclease, nuclease S7 (Roche), dissolved in water at $\sim 10$ units $/ \mu \mathrm{L}$

Micrococcal nuclease (Mnase) reaction buffer (50 mu Tris-Cl at pH 7.9, $5 \mathrm{~mm} \mathrm{CaCl}_{2}$ )

$\mathrm{NaCl}(5 \mathrm{M})$

$\mathrm{NaOAc}(3 \mathrm{M}$ at $\mathrm{pH} 5.2 ; 0.15 \mathrm{M}$ at $\mathrm{pH} 5.2)$

Novex loading buffer (Invitrogen)

Novex NuPAGE precast 10\% Bis-Tris gel

NuSieve agarose (2\%)

PBS for CLIP $<\mathrm{R}>$

Phenol:chloroform (1:1)

PK buffer $<\mathrm{R}>$

PK buffer $+7 \mathrm{M}$ urea (must be fresh)

$\mathrm{PNK}+\mathrm{EGTA}$ buffer (PNK buffer with $20 \mathrm{~mm}$ EGTA in place of $10 \mathrm{mM} \mathrm{MgCl}{ }_{2}$ )

Polynucleotide kinase (PNK) buffer $<\mathrm{R}>$

Polyacrylamide gel (10\% denaturing)

Protein A Dynabeads (Dynal 100.02)

Proteinase $\mathrm{K}$ in $\mathrm{PK}$ buffer $(4 \mathrm{mg} / \mathrm{mL})$

PXL buffer $<\mathrm{R}>$

PXL100 buffer (PXL buffer with $100 \mathrm{~mm}$ additional $\mathrm{NaCl}$ over that present in PBS for CLIP) PXL400 buffer (PXL buffer with $400 \mathrm{~mm}$ additional $\mathrm{NaCl}$ over that present in PBS for CLIP) QIAEX II Gel Extraction Kit (QIAGEN) 
R.B. Darnell

Rainbow marker (Amersham RPN800)

RNase A (USB 70194Y)

RNasin (Promega) or RNaseOUT (Invitrogen)

RQ1 DNase (Promega)

RSB100 cell lysis buffer $<$ R $>$

Sodium phosphate $(0.1 \mathrm{M}, \mathrm{pH} 8.1)$

SuperScript III (Invitrogen)

SuperScript RT buffer $(5 \times)$

SYBR Gold (Molecular Probes)

T4 PNK enzyme (New England Biolabs M0201L)

T4 RNA ligase (Fermentas)

T4 RNA ligase buffer (10×; Fermentas)

TBE $(5 \times)$

TEMED

Urea (Fisher U15-3)

Equipment

Autoradiography equipment and X-ray film

Freezer

Geiger counter

Gel electrophoresis apparatus and power supply

Luminescent stickers

Magnetic rack

Microcentrifuge tubes $(1.5 \mathrm{~mL})$

Nitrocellulose (BA85, S\&S)

Novex NuPage precast gels (10\% Bis-Tris; Invitrogen)

Novex wet-transfer apparatus

Pipettor tip (1 mL, $200 \mu \mathrm{L})$

Plastic pipette (5 or $10 \mathrm{~mL}$ )

Plastic wrap

Rotating wheel

Rotor (TLA 120.2 [Beckman] with polycarbonate tubes)

Scalpel

Scintillation counter

Sonicator

SpeedVac

Thermal cycler

Thermomixer R (Eppendorf)

Tissue culture plates

Ultramicrocentrifuge (Beckman)

UV box (e.g., Stratalinker 2400, Stratagene) 
The protocol takes several days and comprises more than 100 steps. There are two points at which options are available depending on the starting material (tissue [Starting Material Option 1] or cultured cells [Starting Material Option 2]) as well as the nuclease used for trimming the cross-linked RNA (mixture of RNase A and RNase T1 before immunoprecipitation [Nuclease Option 1] or micrococcal nuclease on beads after immunoprecipitation [Nuclease Option 2]) (Fig. 1). In all cases, however, the starting material is first irradiated with UV to cross-link proteins to nucleic acids in vivo. Second, a lysate is prepared from the cross-linked material, and aliquots are treated with dilutions of nuclease to trim the cross-linked RNAs to a size of 50-150 nucleotides. The lysates are cleared of ribosomes and then incubated with beads bearing antibody against the protein of interest. After binding of the protein of interest (plus its covalently cross-linked RNA target fragments) to the antibody-bead matrix, unbound proteins are washed off and a series of reactions is performed on the cross-linked RNAs while they are still attached to the protein and bound to the beads. The cross-linked RNA is dephosphorylated (at both its $3^{\prime}$ and 5' ends) with phosphatase, and an RNA linker (with a blocked 3' end to prevent multiple ligation events) is attached to the $3^{\prime}$ end of the cross-linked fragments using $R N A$ ligase. The $5^{\prime}$ end of the cross-linked RNA is then phosphorylated and labeled by PNK in the presence of $\left[\gamma^{-32} P\right]$ ATP. The labeled RNA-protein complexes are resolved on a denaturing protein gel and radioactive material migrating $\sim 20$ kDa more slowly than the native uncross-linked proteins is isolated, ligated to a $5^{\prime} R N A$ linker, purified, and then RT-PCR-amplified using primers for the linker sequences. These products can then be cloned or subjected to sequencing by further steps. The derived sequences identify the genomic source(s) of the cross-linked RNA.

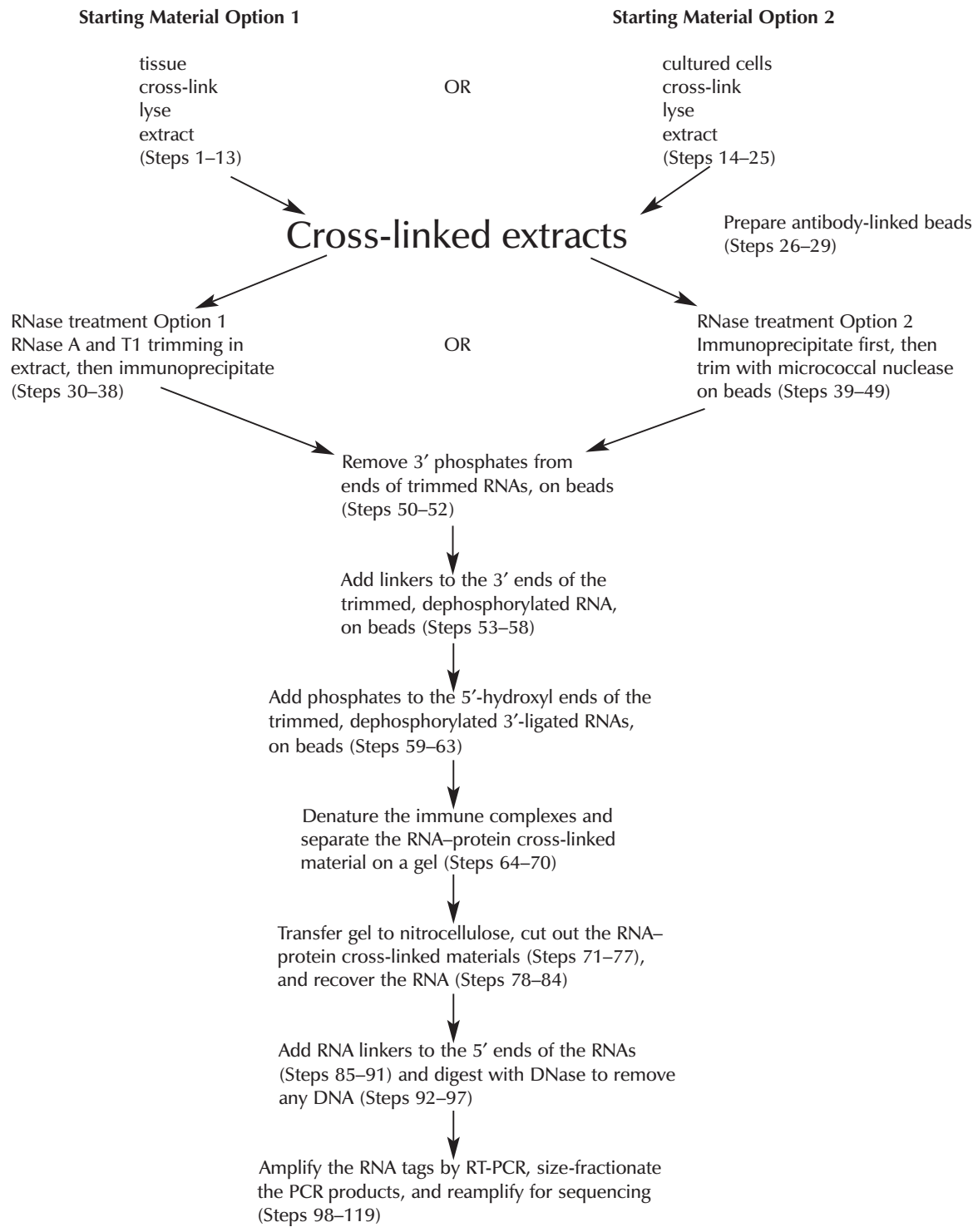

FIGURE 1. Outline of CLIP protocol. 
R.B. Darnell

\section{Starting Material Option 1: UV Cross-Linking of Tissues}

1. Harvest tissue (e.g., material equivalent to one mouse brain $[\sim 500 \mathrm{mg}]$ suffices for neuronal RNA-binding proteins). If necessary, allow tissue to sit in ice-cold PBS for CLIP (alternatively, HBSS can be used instead for brain tissue) until harvest is complete.

2. Disrupt the tissue. Add 10 tissue sample volumes of PBS for CLIP (or HBSS) and break up the tissue by passage into and out of a 5 - or $10-\mathrm{mL}$ plastic pipette. Using a $5-\mathrm{mL}$ plastic pipette to which a 1-mL pipettor tip has been attached, disrupt further, and then finish by using a 200$\mu \mathrm{L}$ pipettor tip attached to a $5-\mathrm{mL}$ pipette. Only very small pieces of tissue should remain. Avoid bubbles.

3. Dispense the suspension into tissue culture plates (placing $10 \mathrm{~mL}$ per each $10-\mathrm{cm}$ tissue culture plate).

4. Irradiate the dish (with the cover off!) three times with $100-400 \mathrm{~mJ} / \mathrm{cm}^{2}$ in a UV box. Mix the suspension between each irradiation.

Because UV light can penetrate a few cell layers, stringent disruption of the tissue to the single-cell level is not necessary.

The amount of cross-linking for each protein should be optimized separately, because each RNA-binding protein will cross-link with different efficiencies. For a preliminary experiment, try 100, 200, and $400 \mathrm{~mJ} /$ $\mathrm{cm}^{2}$ and then use the shortest condition that gives $>70 \%$ of the maximum signal.

5. Collect the suspension, pellet the cells at $2500 \mathrm{rpm}$ for $3 \mathrm{~min}$ at $4^{\circ} \mathrm{C}$, resuspend pellet in $\sim 3 \times$ pellet volumes of PBS for CLIP, and distribute $1 \mathrm{~mL}$ of suspension to microcentrifuge tubes.

6. Centrifuge quickly at $4^{\circ} \mathrm{C}$, remove the supernatant, and freeze the cell pellets at $-80^{\circ} \mathrm{C}$ until use. Each tube should have $\sim 200 \mu \mathrm{L}$ of cells.

7. When ready to continue, thaw each tube of cross-linked cells up to $\sim 1 \mathrm{~mL}$ using PXL buffer. Allow the tube to sit on ice for 10 min to lyse cells and solubilize complexes.

If tissue is resistant to lysis, as is, e.g., adult brain tissue, sonication may be necessary at this step.

8. Add $11 \mu \mathrm{L}$ of $0.1 \mathrm{~m}$ DTT to each tube. Then add $30 \mu \mathrm{L}$ of RNaseOUT or RNasin and $60 \mu \mathrm{L}$ of RQ1 DNase to each tube. Incubate on the Thermomixer at $1200 \mathrm{rpm}$ for $15 \mathrm{~min}$ at $37^{\circ} \mathrm{C}$. Invert the tubes after $8 \mathrm{~min}$.

It is critical to add DTT to the solution because the RNase inhibitors require a minimum of $1 \mathrm{~mm} \mathrm{DTT} \mathrm{to}$ maintain activity.

9. Incubate for $5 \mathrm{~min}$ on ice.

10. Add EDTA to a final concentration of $20 \mathrm{~mm}$.

11. Centrifuge the lysates in a prechilled ultramicrocentrifuge (polycarbonate tubes in TLA 120.2 rotor) at $49,000 \mathrm{rpm}$ for $20 \mathrm{~min}$ at $4^{\circ} \mathrm{C}$.

If the protein of interest sticks to ribosomes under these conditions, or ribosomal complexes or other large RNPs are being studied, this step should be modified so that the target protein stays in the supernatant, or the step should be skipped. If so, beware that spurious cross-linking to rRNA may be observed.

12. Transfer 120 - to $140-\mu \mathrm{L}$ aliquots of the supernatants to new $1.5-\mathrm{mL}$ microcentrifuge tubes.

13. Proceed to prepare the Dynabead-antibody complexes section (Step 26).

Starting Material Option 2: UV Cross-Linking of Cultured Cells

14. Grow the cells in 100- or 150-mm culture plates. For a typical experiment, set up three plates and irradiate two, reserving the other as a "no UV" control.

Cell culture is a useful way to study proteins for which no suitable antibody is readily available. By expressing epitope-tagged proteins for which good antibodies specific for the tag are available, different proteins can be isolated in parallel experiments using the same antibody. The use of some tags (or their antibodies) has been observed to lead to copurification of nontarget RNA-binding proteins, so we recommend that control purifications on untagged extracts be performed as well. 
15. Rinse cell layers once with PBS for CLIP and place the plates in a Stratalinker (with the cover off!). Irradiate one time for $100-400 \mathrm{~mJ} / \mathrm{cm}^{2}$ in the Stratalinker.

Because adherent cells grow in a single layer, a single UV exposure may be sufficient for uniform crosslinking.

The amount of cross-linking for each protein should be optimized separately, because each RNA-binding protein will cross-link with different efficiencies. For a preliminary experiment, try 100, 200, and $400 \mathrm{~mJ} /$ $\mathrm{cm}^{2}$ and then use the shortest condition that gives $>70 \%$ of the maximum signal.

16. Wash the cells twice with $5 \mathrm{~mL}$ of cold PBS for CLIP.

17. Add $400 \mu \mathrm{L}$ of a cell lysis buffer (e.g., RSB100) per plate. Scrape the cells from the dish and collect into a microcentrifuge tube.

RSB100 contains NP-40 and Triton X-100 and is useful for HEK293 cells, but other detergents may work better for other cell lines and experimentation may be necessary.

18. Place the cells on ice for 5 min so that lysis becomes complete.

19. Centrifuge the lysate in a microcentrifuge at $10,000 \mathrm{rpm}$ for $10 \mathrm{~min}$ at $4^{\circ} \mathrm{C}$.

20. Transfer the supernatant to a new $1.5-\mathrm{mL}$ microcentrifuge tube. Combine the +UV supernatants at this point.

21. Add $11 \mu \mathrm{L}$ of $0.1 \mathrm{~m}$ DTT. Then add $30 \mu \mathrm{L}$ of RNaseOUT or RNasin and $60 \mu \mathrm{L}$ of RQ1 DNase to each tube. Incubate on the Thermomixer at $1200 \mathrm{rpm}$ for $15 \mathrm{~min}$ at $37^{\circ} \mathrm{C}$. Invert the tubes after $8 \mathrm{~min}$.

It is critical to add DTT to the solution because the RNase inhibitors require a minimum of $1 \mathrm{~mm} D T T$ to maintain activity.

22. Incubate for $10 \mathrm{~min}$ at $37^{\circ} \mathrm{C}$.

23. Add EDTA to a final concentration of $20 \mathrm{~mm}$.

24. Centrifuge the lysates in a prechilled ultramicrocentrifuge (polycarbonate tubes in TLA 120.2 rotor) at $49,000 \mathrm{rpm}$ for $20 \mathrm{~min}$ at $4^{\circ} \mathrm{C}$.

If the protein of interest sticks to ribosomes under these salt conditions, or ribosomal complexes or other large RNPs are being studied, this step should be modified so that the target protein stays in the supernatant, or the step should be skipped. If so, be aware that spurious cross-linking to rRNA may be observed.

25. Transfer 120 - to $140-\mu \mathrm{L}$ aliquots of the supernatants to new $1.5-\mathrm{mL}$ microcentrifuge tubes.

Prepare the Dynabead-antibody complexes

26. For each 120-140 $\mu \mathrm{L}$ of lysate, use $400 \mu \mathrm{L}$ of Protein A-Dynabead suspension.

Dynabeads are paramagnetic beads that can be collected against the side of the tube using a magnetic rack, or they can be centrifuged briefly in a microcentrifuge (2 min at 10,000 rpm). An advantage of the magnetic rack is that supernatant fluid can be removed while the magnetic force is in place, preventing loss of the beads as occurs during resuspension of pelleted beads.

27. Wash the beads three times with 0.1 m sodium phosphate ( $\mathrm{pH} 8.1$ ).

The high $\mathrm{pH}$ buffer increases antibody capture by Protein A. However, any or all of the immunoprecipitation buffers may need to be optimized for each individual antibody used. For example, some antibodies do not work with the deoxycholate in the wash buffer. If the antibody to be used is mouse IgG ${ }_{1}$, which interacts poorly with Protein A, the beads can be preincubated with rabbit antimouse IgG. The rabbit antimouse antibody will act as an adapter, binding to the Protein A by its constant region, and then to the constant region of the mouse $\lg G_{1}$.

28. Resuspend the beads in $320 \mu \mathrm{L}$ of $0.1 \mathrm{~m}$ sodium phosphate ( $\mathrm{pH} 8.1$ ) and add $80 \mu \mathrm{L}$ of an appropriate concentration of antibody.

29. Rotate the tubes for 30-45 min at room temperature. Wash three times with PXL buffer. If not yet ready to add cross-linked lysate, leave beads in the last wash until ready, but use them the same day as they are made. 
R.B. Darnell

\section{RNase Treatment Option 1: Trim the RNA Tag with RNase A and T1 Mix}

This option uses a mixture of two difficult-to-control nucleases in solution before the cross-linked material is immunoprecipitated. RNase treatment Option 2 uses micrococcal nuclease, applied to the immunoprecipitate after capture of the cross-linked material. This enzyme is easy to control with the use of EGTA because the enzyme is strictly calcium dependent. If using RNase treatment Option 2, go to Step 39.

30. Prepare the following RNase A/T1 solutions (Ambion, cocktail of RNase A and T1):

$\begin{array}{ll}1 \times & \text { neat } \\ 1: 10 & 1 \mu \mathrm{L} \text { RNase: } 9 \mu \mathrm{L} \text { PXL } \\ 1: 50 & 1 \mu \mathrm{L} \text { RNase: } 49 \mu \mathrm{L} \text { PXL } \\ 1: 500 & 1 \mu \mathrm{L} \text { RNase: } 499 \mu \mathrm{L} \text { PXL }\end{array}$

Optimal RNase concentrations must be determined empirically for each RNA-binding protein of interest. The conditions above represent a good starting point. Ideally a UV-dependent, RNase-sensitive complex will be observed following immunoprecipitation and autoradiography.

31. Bring each tube of cross-linked lysate from either Step 12 (Option 1: tissues) or Step 25 (Option 2: cell lines) up to $\sim 1 \mathrm{~mL}$ using PXL buffer. Remove $10 \mu \mathrm{L}$ for immunoblot analysis. Save another $20 \mu \mathrm{L}$ for total control (this will be used to clone or sequence the control RNA tags present in the total pool of RNA-binding proteins).

32. Set up the following six reactions by adding $1 \mu \mathrm{L}$ of the appropriate RNase dilutions per 100 $\mu \mathrm{L}$ of the appropriate extract and incubate for $10 \mathrm{~min}$ at $37^{\circ} \mathrm{C}$. Be sure to include the "no UV" and "no antibody" controls:

Standard controls and RNase dilutions for typical CLIP

\begin{tabular}{lllllll}
\hline [RNase $]$ & $1: 10$ & $1: 10$ & Undiluted & $1: 10$ & $1: 50$ & $1: 500$ \\
Antibody & + & - & + & + & + & + \\
Beads & + & + & + & + & + & + \\
UV & - & + & + & + & + & + \\
Tube & 1 & 2 & 3 & 4 & 5 & 6
\end{tabular}

33. Add an equal volume of $2 \times$ PXL to each tube to denature the extract and inactivate RNases.

34. Add $450 \mu \mathrm{L}$ of PXL and $200 \mu \mathrm{L}$ of antibody beads to each tube, as indicated in the table above.

35. Incubate the tubes for $1 \mathrm{~h}$ at $4^{\circ} \mathrm{C}$.

36. Recover the beads using the magnetic rack and remove the lysate. Save an aliquot for a western blot to determine the efficiency of immunoprecipitation.

37. Wash the beads with $1000 \mu \mathrm{L}$ of the following ice-cold buffers:

i. Twice with PXL

ii. Twice with PXL-400

iii. Twice with $1 \times$ PNK buffer

38. Proceed to the remove phosphates from the RNA ends section below (Step 50).

\section{RNase Treatment Option 2: Trim the RNA Tag with Micrococcal Nuclease (on Bead)}

This option trims the RNA in the cross-linked material after it is captured on the beads. It may be easier to control digestion with this enzyme as compared to RNases $A$ and $T 1$.

39. Adjust each tube of cross-linked lysate from Step 12 (Option 1: tissues) or Step 25 (Option 2: cultured cells) to $\sim 1 \mathrm{~mL}$ using PXL buffer. Remove $10 \mu \mathrm{L}$ for immunoblot analysis. Save another $20 \mu \mathrm{L}$ for total control (this will be used to clone or sequence the control RNA tags present in the total pool of RNA-binding proteins).

40. Aliquot the antibody beads (from Step 29) and remove the last wash from each tube. Then, add each aliquot of lysate to one tube of antibody-coated beads. Rotate beads-lysate mix for $1 \mathrm{~h}$ at $4^{\circ} \mathrm{C}$. 
41. Collect the beads in the magnetic rack, remove the supernatant, and save $10 \mu \mathrm{L}$ for immunoblot analysis: This aliquot should be depleted of the target protein.

42. Wash beads twice with ice-cold PXL buffer.

43. Wash twice with ice-cold PXL100 buffer.

44. Wash twice with ice-cold PXL400 buffer.

If this step decreases the efficiency of immunoprecipitation, it can be omitted.

45. Wash twice with ice-cold $1 \times$ PNK buffer.

46. Dilute micrococcal nuclease with $1 \times$ MNase reaction buffer. Optimize the reaction by making a series of dilutions of $15,2,0.2$, and 0.02 units of MNase in $500-\mu \mathrm{L}$ aliquots of MNase reaction buffer. The 0.2-unit dilution seems to work best for cultured cell extracts; however, this may vary with the protein being studied. The 15-unit dilution will be the high (complete digestion) MNase control.

47. Add $500 \mu \mathrm{L}$ of diluted MNase to the washed beads containing the antibody cross-linked RNA-protein complexes from Step 45.

48. Incubate the mixture at $1200 \mathrm{rpm}$ on a Thermomixer for $1 \mathrm{~min}$ at $37^{\circ} \mathrm{C}$ and then place the mixture on ice. Approximately every $3 \mathrm{~min}$ for the next $10 \mathrm{~min}$, place the mixture on the Thermomixer for $15 \mathrm{sec}$, returning the tube to the ice between mixing.

49. Wash the beads with the following series of ice-cold buffers:

i. Twice with $1 \times$ PNK + EGTA buffer (EGTA will chelate the $\mathrm{Ca}^{2+}$ and quench the MNase activity)

ii. Twice with PXL buffer

iii. Twice with $1 \times$ PNK buffer

Remove Phosphates from the RNA Ends (on Bead)

50. Set up the reaction with calf intestinal alkaline phosphatase (CIP) as follows:

$\begin{array}{lr}\text { Dephosphorylation buffer }(10 \times) & 8 \mu \mathrm{L} \\ \mathrm{CIP} & 3 \mu \mathrm{L} \\ \mathrm{H}_{2} \mathrm{O} & 69 \mu \mathrm{L} \\ \text { Total } & 80 \mu \mathrm{L}\end{array}$

51. Add the mixture to the beads and incubate in the Thermomixer for $10 \mathrm{~min}$ at $37^{\circ} \mathrm{C}$. Set the mixer to shake at $1000 \mathrm{rpm}$ for $15 \mathrm{sec}$ every $3 \mathrm{~min}$.

52. Wash the beads with the following series of ice-cold buffers:

i. Twice with PNK + EGTA buffer

ii. Twice with PNK buffer

iii. Twice with $0.1 \mathrm{mg} / \mathrm{mL}$ BSA in RNase-free water

BSA enhances T4 RNA ligase efficiency and reduces aggregation of the beads.

Add RNA Linkers to the 3' End of the Fragments with RNA Ligase (on Bead)

53. Make up the linker mix by adding

$\begin{array}{lr}3^{\prime} \mathrm{RNA} \text { linker at } 20 \mathrm{pmol} / \mu \mathrm{L} & 8 \mu \mathrm{L} \\ \mathrm{H}_{2} \mathrm{O} & 32 \mu \mathrm{L} \\ \text { Total } & 40 \mu \mathrm{L}\end{array}$


R.B. Darnell

54. Add $40 \mu \mathrm{L}$ of the linker mix to each tube of beads.

55. Make up the RNA ligase mix by adding

$\begin{array}{lr}\text { T4 RNA ligase buffer }(10 \times) & 8 \mu \mathrm{L} \\ \text { BSA }(0.2 \mu \mathrm{g} / \mu \mathrm{L}) & 8 \mu \mathrm{L} \\ \text { ATP }(10 \mathrm{~mm}) & 8 \mu \mathrm{L} \\ \text { T4 RNA ligase } & 2 \mu \mathrm{L} \\ \mathrm{H}_{2} \mathrm{O} & 14 \mu \mathrm{L} \\ \text { Total } & 40 \mu \mathrm{L}\end{array}$

56. Add $40 \mu \mathrm{L}$ of ligase mix to each tube of beads (final linker concentration is $2 \mathrm{pmol} / \mu \mathrm{L}$ ).

57. Incubate the mixture in the Thermomixer overnight at $16^{\circ} \mathrm{C}$. Set the mixer to shake at 1000 rpm for 15 sec every 5 min.

The linker is blocked at its 3' end with a puromycin moiety and thus only a single linker can be added to a given RNA.

58. Wash the beads three times with PNK buffer.

Phosphorylate the 5' Ends of the RNAs with PNK (on Bead)

59. Make the PNK mix by adding

$\begin{array}{lr}\text { PNK buffer }(10 \times) & 8 \mu \mathrm{L} \\ {\left[\gamma_{-}{ }^{32} \mathrm{P}\right] \text { ATP }(10 \mu \mathrm{Ci} / \mu \mathrm{L})} & 2 \mu \mathrm{L} \\ \text { T4 PNK enzyme } & 4 \mu \mathrm{L} \\ \mathrm{H}_{2} \mathrm{O} & 66 \mu \mathrm{L} \\ \text { Total } & 80 \mu \mathrm{L}\end{array}$

60. Add $80 \mu \mathrm{L}$ of PNK mix to each sample and incubate in the Thermomixer for 10 min total at $37^{\circ} \mathrm{C}$. Set the mixer to shake at $1000 \mathrm{rpm}$ for $15 \mathrm{sec}$ every $4 \mathrm{~min}$.

61. Add $10 \mu \mathrm{L}$ of $1 \mathrm{~mm}$ ATP (nonradioactive) and allow the reaction to proceed for an additional $5 \mathrm{~min}$.

62. Wash three times with PNK + EGTA.

CAUTION: These washes are radioactive and should be disposed of properly!

63. Resuspend the beads in $30 \mu \mathrm{L}$ of PNK + EGTA.

\section{Resolve the RNA-Protein Cross-Linked Complexes on a Gel}

This step makes use of precast gels sold under the name Novex NuPAGE (Invitrogen). They are different from the commonly used "Laemmli" SDS polyacrylamide gels in several ways. The most important difference is that the buffer system does not produce a high $\mathrm{pH}$ wave through the sample during electrophoresis, thus protecting the RNA tags from alkaline hydrolysis.

Depending on the size of the protein of interest, the presence of antibody in the sample may interfere with resolution of the protein and its RNA tags. The antibody heavy chain $(\sim 50 \mathrm{kDa})$ and light chain $(\sim 25 \mathrm{kDa})$ can be separated and resolved from each other in the presence of a reducing agent such as $\beta$-mercaptoethanol or DTT. If the protein of interest is larger than and can be separated from the 50-kDa heavy chain, we recommend that a reducing agent be added. If the protein of interest is the same size or smaller than $50 \mathrm{kDa}$, we do not recommend that the sample be reduced; this will leave the disulfide bridges in the antibody protein intact and it will not migrate near the bands of interest in the gel.

64. Add to the beads $30 \mu \mathrm{L}$ of Novex loading buffer (with or without reducing agent, depending on the size of the protein of interest).

65. Mix the $20 \mu \mathrm{L}$ of total control (supernatant removed from lysate before the immunoprecipitation at Steps 31 or 39 , depending on which nuclease was used) and $10 \mu \mathrm{L}$ of Novex loading buffer.

66. Incubate the mixture in the Thermomixer at $1000 \mathrm{rpm}$ for $10 \mathrm{~min}$ at $70^{\circ} \mathrm{C}$. Collect the beads against the side of the tube and remove the supernatant for loading. 
67. Split and load the sample from each tube of beads into two wells of a 10-well precast Novex NuPAGE 10\% Bis-Tris gel.

68. Load the prestained markers in a side well of the gel.

Some prestained molecular-weight markers may run differently on Novex NuPAGE gels. We recommend using the Rainbow Marker (Amersham RPN800), which runs at the expected molecular weights on this gel system.

69. When the dye front has migrated to the end of the gel, disassemble the gel and transfer it to S\&S BA-85 nitrocellulose using the Novex wet-transfer apparatus.

BA-85 is pure nitrocellulose and a little fragile, but it works better for the extraction step later.

Some of the radioactivity in the loaded sample will not be retained on the gel. Some will be in the lower buffer, which results from carryover of free ATP and small free RNAs that were not washed from the beads after the kinase step. Free RNA $<100$ nucleotides long will migrate faster than the 30-kDa marker.

70. After transfer, gently rinse the nitrocellulose filter in PBS for CLIP and carefully blot the side that was away from the gel on Kimwipes. Wrap the membrane in plastic wrap and expose to $\mathrm{X}$-ray film for autoradiography (see Fig. 2).

Free RNA will not bind to the membrane and will be lost in the transfer step. The film must be aligned to the blot so that the proper material can be cut out. Apply luminescent stickers to ensure that this alignment is as accurate as possible.

Depending on the protein and amount of starting material, a strong signal may be seen on the autoradiogram after 30 min of exposure. If much less material is used, an overnight exposure will sometimes be necessary to see a decent signal.

\section{Recovering the Cross-Linked RNA}

71. Go to the next step if the overdigested (highest nuclease concentration) sample lane has a band close to the expected molecular mass of the protein of interest (as in Fig. 2).

72. Calculate the distance between the protein of interest and the closest contaminating bands and estimate the relative signal strength of the protein of interest relative to other bands.

It should be possible to purify RNAs specific for the protein of interest if it migrates $>10 \mathrm{kDa}$ away from any other strong protein band and its signal is as strong as the other bands on the gel.

73. Estimate the position of migration of the protein of interest cross-linked to an original trimmed tag of 50 nucleotides, using the following considerations: The average molecular mass of 50 nucleotides of RNA is $16.2 \mathrm{kDa}$. Because each original tag now contains a 20 -nucleotide-long linker (L3), the average size of RNA desired will thus be 70 nucleotides, which should cause the protein to migrate on average $\sim 20 \mathrm{kDa}$ more slowly than the molecular mass of the free protein. Because the nuclease trimming of the tags generates heterogeneous ends, the tag sizes will vary from $\sim 10$ to 150 nucleotides and thus the complex will appear as diffuse radioactivity.

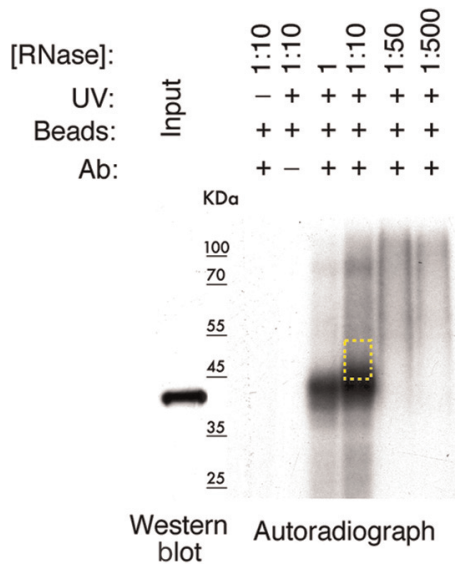

FIGURE 2. A sample CLIP experiment for hnRNP A1, a 36-kDa RNA-binding protein. The strong cross-linked bands at $42 \mathrm{kDa}$ in lanes 3 and 4 are dependent on UV treatment and antibody in the immunoprecipitation as well as a proper level of ribonuclease activity. The region shown in the autoradiogram (fourth lane from the left, dashed square) should be excised from the gel and treated to continue isolation of the RNA. (Courtesy of Jeremy Sanford, University of California, Santa Cruz.) 
R.B. Darnell

74. Use a clean scalpel blade to cut a band from the nitrocellulose spanning $\sim 10-20 \mathrm{kDa}$ above the molecular mass of the free protein of interest.

75. In addition, cut two bands below and above this band, with $\sim 15 \mathrm{kDa}$ distance between the target band and these side fractions.

With these samples, it may be possible to determine whether any other RNA-binding proteins are contaminating the sample.

76. From the total control lane, cut out a very wide band from $30 \mathrm{kDa}$ to almost the top of the gel. This control should contain RNA tags bound to all the cellular RNA-binding proteins with size from 10 to $200 \mathrm{kDa}$. It should not contain free RNA with a size $<100 \mathrm{kDa}$, because such RNAs migrate lower than $30 \mathrm{kDa}$. This control tag can later be compared with the tags that bound to the protein of interest.

77. Cut each band into little pieces and place the pieces from each band into a microcentrifuge tube. Count radioactivity in a scintillation counter to determine the yield of each.

Isolate the RNA from the Nitrocellulose

78. Make a $4-\mathrm{mg} / \mathrm{mL}$ proteinase $\mathrm{K}$ stock solution in $1 \times \mathrm{PK}$ buffer. Preincubate this stock for 20 min at $37^{\circ} \mathrm{C}$ to ensure digestion of any RNases.

79. Add $200 \mu \mathrm{L}$ of proteinase $\mathrm{K}$ solution to each tube of isolated nitrocellulose pieces. Incubate on the Thermomixer at $1000 \mathrm{rpm}$ for $20 \mathrm{~min}$ at $37^{\circ} \mathrm{C}$.

80. Add $200 \mu \mathrm{L}$ of fresh $\mathrm{PK}+7 \mathrm{~m}$ urea solution. Incubate on the Thermomixer at $1000 \mathrm{rpm}$ for another $20 \mathrm{~min}$ at $37^{\circ} \mathrm{C}$.

81. Add $400 \mu \mathrm{L}$ of phenol equilibrated with $0.15 \mathrm{~m} \mathrm{NaOAc}$ (pH 5.2) and $130 \mu \mathrm{L}$ of chloroform: isoamyl alcohol (49:1) to the suspension. Incubate on the Thermomixer at $1000 \mathrm{rpm}$ for 20 $\min$ at $37^{\circ} \mathrm{C}$.

82. Centrifuge the tubes in a microcentrifuge at $12,000 \mathrm{rpm}$ for $5 \mathrm{~min}$ at room temperature. Remove the aqueous phase to a new tube.

83. Add $50 \mu \mathrm{L}$ of $3 \mathrm{~m} \mathrm{NaOAc}$ ( $\mathrm{pH} 5.2$ ), $0.5 \mu \mathrm{L}$ of $5 \mathrm{mg} / \mathrm{mL}$ glycogen, and $1 \mathrm{~mL}$ of ethanol: isopropanol (1:1) to the aqueous phase. Mix well.

Glycogen helps to precipitate small quantities of RNA, but too much may inhibit RNA ligase.

84. Precipitate overnight at $-20^{\circ} \mathrm{C}$.

Ligate RNA Linkers to the $5^{\prime}$ Ends of the Tags

85. Centrifuge the RNA in a microcentrifuge at $12,000 \mathrm{rpm}$ for $10 \mathrm{~min}$ at $4^{\circ} \mathrm{C}$. To determine whether the precipitation was successful, use a Geiger counter to detect evidence of radioactivity.

86. Rinse the pellet twice with $150 \mu \mathrm{L}$ of ice-cold $75 \%$ ethanol, centrifuging the precipitate after each rinse at $12,000 \mathrm{rpm}$ for $5 \mathrm{~min}$ at $4^{\circ} \mathrm{C}$.

This should minimize loss of the precipitate and ensure removal of salt.

87. Dry briefly $(<2 \mathrm{~min})$ in the SpeedVac. Count the RNA in a scintillation counter.

88. Resuspend the pellet in $6 \mu \mathrm{L}$ of $\mathrm{H}_{2} \mathrm{O}$.

89. Set up the RNA ligation premix:

$\begin{array}{lr}\text { T4 RNA ligase buffer }(10 \times) & 1 \mu \mathrm{L} \\ \text { BSA }(0.2 \mu \mathrm{g} / \mu \mathrm{L}) & 1 \mu \mathrm{L} \\ \text { ATP }(10 \mathrm{~mm}) & 1 \mu \mathrm{L} \\ \text { T4 RNA ligase (3 units) } & 0.1 \mu \mathrm{L} \\ \text { L5 RNA linker at } 20 \mathrm{pmol} / \mu \mathrm{L} & 1 \mu \mathrm{L} \\ \text { Total } & 4.1 \mu \mathrm{L}\end{array}$

90. Add $5.9 \mu \mathrm{L}$ of RNA resuspended in $\mathrm{H}_{2} \mathrm{O}$ to the premix. The final volume is $10 \mu \mathrm{L}$ total. 
91. Incubate the mixture for $>2 \mathrm{~h}$ at $16^{\circ} \mathrm{C}$. Try to avoid overnight.

Ligation can only occur between the phosphorylated 5' end of the RNA tag and the 3' OH of the 5' linker The $5^{\prime}$ linker itself cannot dimerize or circularize (it has a 5' OH that is not reactive), and the CLIP tag- $3^{\prime}$ linker cannot dimerize or circularize (it is blocked by puromycin at its $3^{\prime}$ end). Extended incubation may lead to RNA fragmentation and undesired ligation events. Do not heat inactivate ligase, because RNA may be degraded with $\mathrm{Mg}^{2+}$ present. Do not inactivate with EDTA, which will bind $\mathrm{Mg}^{2+}$, inhibiting the DNase treatment.

\section{Remove any Contaminating DNA from the RNA Tags}

92. Add to the RNA ligation reaction:

$\begin{array}{lc}\mathrm{H}_{2} \mathrm{O} & 78 \mu \mathrm{L} \\ \text { DTT }(0.1 \mathrm{~m}) & 1 \mu \mathrm{L} \\ \text { DNase I buffer } 1(10 \times) & 1 \mu \mathrm{L} \\ \text { RNasin } & 5 \mu \mathrm{L} \\ \text { RQ1 DNase } & 5 \mu \mathrm{L}\end{array}$

93. Incubate the mixture for $20 \mathrm{~min}$ at $37^{\circ} \mathrm{C}$.

This DNase step reduces the production of spurious PCR products in subsequent amplification rounds and ensures that amplicons are derived from RNA by RT-PCR.

94. Extract the RNA as follows: To the DNase reaction, add $300 \mu \mathrm{L}$ of $\mathrm{H}_{2} \mathrm{O}, 300 \mu \mathrm{L}$ of phenol equilibrated with $0.15 \mathrm{~m} \mathrm{NaOAc}$ ( $\mathrm{pH}$ 5.2), and $100 \mu \mathrm{L}$ of chloroform:isoamyl alcohol (49:1).

95. Vortex the mixture to emulsify and then centrifuge at $10,000 \mathrm{rpm}$ for $5 \mathrm{~min}$ at room temperature to separate the phases. Remove the aqueous layer to a new tube.

96. Precipitate the RNA from the aqueous layer by adding $50 \mu \mathrm{L}$ of $3 \mathrm{~m} \mathrm{NaOAc}(\mathrm{pH} 5.2$ ), $1 \mu \mathrm{L}$ of 5 $\mathrm{mg} / \mathrm{mL}$ glycogen, and $1 \mathrm{~mL}$ of ethanol:isopropanol (1:1).

97. Precipitate overnight ( or $<2 \mathrm{~h}$ ) at $-20^{\circ} \mathrm{C}$.

\section{Amplify the Linker-Ligated Tags by RT-PCR}

98. Centrifuge the RNA in a microcentrifuge at $12,000 \mathrm{rpm}$ for $10 \mathrm{~min}$ at $4^{\circ} \mathrm{C}$. To determine whether the precipitation was successful, use a Geiger counter to detect evidence of radioactivity in the pellet.

99. Rinse the pellet twice with $150 \mu \mathrm{L}$ of ice-cold $75 \%$ ethanol, centrifuging the precipitate after each rinse at 12,000 $\mathrm{rpm}$ for $5 \mathrm{~min}$ at $4^{\circ} \mathrm{C}$.

This should minimize loss of the precipitate and ensure removal of salt.

100. Dry the pellet briefly ( $<2 \mathrm{~min})$ in the SpeedVac. Count the RNA in a scintillation counter.

101. Resuspend the pellet in $8 \mu \mathrm{L}$ of $\mathrm{H}_{2} \mathrm{O}$. This is the ligated RNA.

102. Mix the $8 \mathrm{~mL}$ of ligated RNA with $2 \mu \mathrm{L}$ of DNA primer P3 $(5 \mathrm{pmol} / \mu \mathrm{L})$.

103. Heat the mixture for $5 \mathrm{~min}$ at $65^{\circ} \mathrm{C}$. Then, chill on ice and centrifuge quickly to collect any droplets that may have formed by condensation.

104. To the RNA + primer mix add:

$\begin{array}{lc}\text { dNTP (3 mm each) } & 3 \mu \mathrm{L} \\ \text { DTT (0.1 m) } & 1 \mu \mathrm{L} \\ \text { SuperScript RT buffer (5×) } & 4 \mu \mathrm{L} \\ \text { RNasin } & 1 \mathrm{~mL} \\ \text { SuperScript III (Invitrogen 18080-044) } & 1 \mu \mathrm{L} \\ \text { Total } & 20 \mu \mathrm{L}\end{array}$

105. Incubate the mixture for $30 \mathrm{~min}$ at $50^{\circ} \mathrm{C}$ and then for $5 \mathrm{~min}$ at $90^{\circ} \mathrm{C}$. Finally, adjust the temperature to $4^{\circ} \mathrm{C}$. 
R.B. Darnell

106. Set up the PCR by mixing:

$$
\begin{array}{lr}
\text { Accuprime Pfx Supermix } & 27 \mu \mathrm{L} \\
\text { P5 primer, 30 pmol } / \mu \mathrm{L} & 0.5 \mu \mathrm{L} \\
\text { P3 primer, 30 pmol/ } / \mu \mathrm{L} & 0.5 \mu \mathrm{L} \\
\text { RT reaction from Step 105 } & 2 \mu \mathrm{L} \\
\text { Total } & 30 \mu \mathrm{L}
\end{array}
$$

107. Cycle as follows in a thermal cycler:

i. Step 1: $95^{\circ} \mathrm{C}$ for $5 \mathrm{~min}$

ii. Step 2: Cycle 25-35 times (depending on the amount of RNA): $95^{\circ} \mathrm{C}$ for $20 \mathrm{sec}, 61^{\circ} \mathrm{C}$ for $30 \mathrm{sec}$, and then $68^{\circ} \mathrm{C}$ for $20 \mathrm{sec}$

iii. Step 3: $68^{\circ} \mathrm{C}$ for $5 \mathrm{~min}$

iv. Step 4: Hold at $4^{\circ} \mathrm{C}$

Purify the PCR-Amplified Tag Sequences

108. Pour a 10\% denaturing polyacrylamide gel. Amounts may vary depending on size. For $20 \mathrm{~mL}$ of the gel mix, add:

$\begin{array}{lr}\text { Urea (Fisher U15-3) } & 8.4 \mathrm{~g} \\ 40 \% \text { acrylamide:bis- } & 5 \mathrm{~mL} \\ \text { acrylamide (19:1) } & \\ \text { TBE }(5 \times) & 4 \mathrm{~mL}\end{array}$

$\mathrm{H}_{2} \mathrm{O} \quad$ to $20 \mathrm{~mL}$ total

109. Immediately before pouring the gel, add $200 \mu \mathrm{L}$ of freshly made $10 \%$ APS and $7.5 \mathrm{~mL}$ of TEMED.

110. Pour the gel and insert the comb. Allow the gel to polymerize.

111. Run the entire PCR on one lane of the gel. Use low-molecular-weight markers (e.g., $3 \mu \mathrm{L}$ per lane Amplisize Molecular Ruler). Do not heat.

112. Visualize DNA by immersing the gel for $10 \mathrm{~min}$ in a 10,000-fold dilution of SYBR Gold in TBE. In the case of the nitrocellulose band representing material migrating $\sim 20 \mathrm{kDa}$ above the free molecular mass of the protein of interest, the DNA amplified from the RNA tags will appear as a diffuse band migrating at $\sim 80-90$ nucleotides (average RNA tag size of $\sim 50$ nucleotides + 36 nucleotides for the linkers). There may be a smear above this size as well, indicating the presence of longer tags. Sharp bands as well as any obvious primer dimers should be avoided.

113. Cut out the DNA of 80-90 nucleotides or greater if present from the gel, avoiding sharp bands. Go for the heterogeneous material. Extract the DNA with the QIAEX II Kit (follow protocol for polyacrylamide gel) and resuspend the extracted DNA in $20 \mu \mathrm{L}$ of $\mathrm{H}_{2} \mathrm{O}$.

This is the amplicon library that represents the pool of RNA sequences that cross-link to the protein of interest. At this point, the library can be cloned and sequenced or sequenced directly using high-throughput sequencing methods. These methods require the addition of specific capture sequences, such as that described below for 454 sequencing.

Add 454 Capture Linkers via Second PCR Step

114. Set up the PCR by mixing:

$\begin{array}{lr}\text { Accuprime Supermix Pfx } & 95 \mu \mathrm{L} \\ \text { P5-454 }(100 \mu \mathrm{M}) & 1 \mu \mathrm{L} \\ \text { P3-454 }(100 \mu \mathrm{M}) & 1 \mu \mathrm{L} \\ \text { QIAEX-II-purified RT-PCR } & 3 \mu \mathrm{L} \\ \text { product from Step 113 } & \\ \text { Total } & 100 \mu \mathrm{L}\end{array}$


115. Cycle as follows in a PCR machine:

i. Step $1: 95^{\circ} \mathrm{C}$ for $5 \mathrm{~min}$

ii. Step 2: Cycle 15-20 times (depending on the amount of RNA): $95^{\circ} \mathrm{C}$ for $15 \mathrm{sec}, 60^{\circ} \mathrm{C}$ for $30 \mathrm{sec}$, and then $68^{\circ} \mathrm{C}$ for $30 \mathrm{sec}$

iii. Step 3: $68^{\circ} \mathrm{C}$ for $5 \mathrm{~min}$

iv. Step 4: Hold at $4^{\circ} \mathrm{C}$

116. Add $200 \mu \mathrm{L}$ of phenol:chloroform, vortex briefly, and then centrifuge at 12,000 rpm for $5 \mathrm{~min}$ at room temperature.

117. Collect the aqueous fraction and add $200 \mu \mathrm{L}$ chloroform:isoamyl alcohol (49:1). Vortex briefly and then centrifuge at 12,000 rpm for $5 \mathrm{~min}$ at room temperature.

118. Collect the aqueous fraction. Add $14 \mu \mathrm{L}$ of $5 \mathrm{~m} \mathrm{NaCl}(0.1 \mathrm{~m}$ final $)$ and $500 \mu \mathrm{L}$ of ethanol $(2.5$ volumes). Precipitate the DNA for $2 \mathrm{~h}$ (or overnight) at $-20^{\circ} \mathrm{C}$.

119. Separate the amplicons on $2 \%$ NuSieve agarose and then gel-purify them. PCR products should be $\sim 125$ bp in length. Extract the DNA with the QIAEX II Kit (follow protocol for agarose gel) and resuspend it in $20 \mu \mathrm{L}$ of $\mathrm{H}_{2} \mathrm{O}$.

Small amounts of amplicons are required for the sequencing (titration runs and full runs). Consult with the sequencing facility to find out how much is required for 454 sequencing, but emphasize that the capture sequences are already present in the library of amplicons if this step has been performed!

In general, the overall success of this procedure is likely to depend on several main factors listed below.

1. The length of time of UV exposure and the yield of cross-links, which depends on the intrinsic geometries of the population of RNA-protein complexes of interest, may vary.

2. Calibrating the trimming of the RNA ends is key to obtaining useful tags for sequencing.

3. The antibody will have characteristic properties that must be considered, especially if comparing CLIP results using different antibodies. Use of tagged proteins of interest and the same antitag antibody may circumvent some of this variation.

4. Cutting the correct region of the nitrocellulose above the unreacted protein band will contribute to the size and complexity of the recovered RNA population.

\section{RELATED INFORMATION}

For further information on CLIP and its uses, see, for example, Ule et al. (2005) and Jensen and Darnell (2008).

PBS for CLIP

$137 \mathrm{~mm} \mathrm{NaCl}$

$2.7 \mathrm{~mm} \mathrm{KCl}$

$10 \mathrm{mM} \mathrm{Na}_{2} \mathrm{HPO}_{4}$

$5 \mathrm{mM} \mathrm{KH}_{2} \mathrm{PO}_{4}$

Adjust the $\mathrm{pH}$ to 7.4. 
R.B. Darnell

\section{PK Buffer}

$100 \mathrm{~mm}$ Tris- $\mathrm{Cl}$ at $\mathrm{pH} 7.5$

$50 \mathrm{~mm} \mathrm{NaCl}$

$10 \mathrm{~mm}$ EDTA

\section{Polynucleotide Kinase (PNK) Buffer}

$50 \mathrm{~mm}$ Tris- $\mathrm{Cl}$ at $\mathrm{pH} 7.4$

$10 \mathrm{mM} \mathrm{MgCl}_{2}$

$0.5 \%$ NP-40

Protease inhibitor cocktail

\section{PXL Buffer}

PBS for CLIP $<\mathrm{R}>$

$0.1 \%$ SDS

$0.5 \%$ deoxycholate

$0.5 \%$ NP-40

Protease inhibitor cocktail

Some antibodies do poorly with deoxycholate; if so, omit it.

\section{RSB100 Cell Lysis Buffer}

$10 \mathrm{~mm}$ Tris- $\mathrm{Cl}$ at $\mathrm{pH} 7.4$

$100 \mathrm{~mm} \mathrm{NaCl}$

$2.5 \mathrm{mM} \mathrm{MgCl}_{2}$

$0.5 \%$ NP-40

$0.5 \%$ Triton X-100

\section{REFERENCES}

Jensen KB, Darnell RB. 2008. CLIP: Crosslinking and immunoprecipitation of in vivo RNA targets of RNA-binding proteins. Methods Mol Biol 488: 85-98.
Ule J, Jensen K, Mele A, Darnell RB. 2005. CLIP: A method for identifying protein-RNA interaction sites in living cells. Methods 37: 376-386. 


\section{CLIP (Cross-Linking and Immunoprecipitation) Identification of RNAs Bound by a Specific Protein}

Robert B. Darnell

Cold Spring Harb Protoc; doi: 10.1101/pdb.prot072132

\begin{tabular}{cc}
$\begin{array}{c}\text { Email Alerting } \\
\text { Service }\end{array}$ & Receive free email alerts when new articles cite this article - click here. \\
\hline Subject & Browse articles on similar topics from Cold Spring Harbor Protocols. \\
Categories & Immunoprecipitation (75 articles) \\
& $\begin{array}{c}\text { Molecular Biology, general (1293 articles) } \\
\text { Proteins and Proteomics, general (575 articles) } \\
\text { RNA (317 articles) } \\
\text { RNA, general (269 articles) }\end{array}$ \\
\hline
\end{tabular}

